\title{
'Singing Songs, Making Places, Creating Selves': Football Songs \& Fan Identity at Sydney FC
}

\author{
Transforming Cultures eJournal, \\ Vol. 4 No 1 April 2009 \\ http://epress.lib.uts.edu.au/journals/TfC
}

\section{Ian Collinson ${ }^{1}$}

\begin{abstract}
The Australian A-League soccer competition was established in 2004. The creation of a new national soccer league precipitated many changes within Australia's football culture. These changes were particularly difficult for the supporters because, with a single exception, all the A-League teams were completely new 'franchises'. The reinvented competition required soccer fans to adopt a new team, to develop new loyalties, new rituals, new places, and consequently a new fan identity. Vital to this act of re-creation has been the collective authorship of a 'new' repertoire of football songs. Football songs and communal singing are central to the traditions and performance of soccer fandom. Football song plays a key, perhaps even determining, role in the creation of fan identity. In this paper I examine the way football songs are used create a fan identity for Sydney's new A-League side: Sydney FC. I argue that the result of Sydney fans' conscious act of cultural creation is a repertoire of songs and chants that, although derived from an increasingly globalised and commodified football culture, is able to articulate a local identity. Moreover, these songs may even be thought to articulate a local and a global fan identity simultaneously, as fans connect local and distant spaces within global soccer culture.
\end{abstract}

\section{Introduction}

Sydney FC came into existence in 2004 as part of the foundation of the Australian national soccer league: the A-League. With South Korean car manufacturer Hyundai as sponsor, the new league offered the promise of an effective and sustainable national football competition. The initiation of the A-League, which replaced the National Soccer League (NSL), created rifts in the football community as the architects of the new regime followed 'a familiar pattern of modernization and re-orientation of the

\footnotetext{
${ }^{1}$ Ian Collinson teaches at the Department of Contemporary Music Studies, Macquarie University and The Learning Centre, UNSW.
} 
game to new, television audiences and rejection of traditional representative roles for clubs in favour of more "rational" market approaches' (Skinner et al, 2008:401). ${ }^{2}$ This 'modernisation' has resulted in all bar two of the NSL teams being demoted to the semiprofessional state leagues. Consequently, football supporters have had to reconsider their allegiances in light of the reorganisation. With the exception of the fans of the Perth Glory and Adelaide United, all football supporters who wished to follow elite club soccer had to adopt a new franchise; fans have had to re-draw what Lawrence Grossberg has famously called their 'mattering maps' and conjure new collective imaginaries in response to the changes in the political economy of football.

Football thrives on tribalism, nostalgia, memory and myth and the affective investments of fans-none of which was immediately available to the followers of the new ALeague clubs. At Sydney FC, the official supporter group, The Cove, has taken on the responsibility for inventing a tradition (Hobsbawm \& Ranger, 1983), including club songs and chants. In this paper I will look at the role that football songs and singing play in the emergent collective imaginary of fans of Sydney FC. ${ }^{3}$ I argue here that the fans' singing articulates, simultaneously, a local and global football fan identity. To aid this discussion I will draw on the views of Cove members themselves, as expressed through their online fan-forum: Sydney-Unofficial.

\section{Fans \& songs}

Football plainsong has been pivotal in the creation of this new Sydney Fan identity because, as Les Back suggests, 'it is primarily through songs and banter that a structure of feeling is produced in football stadiums' (Back, 2001: 311). In using the term 'plainsong' to describe massed football singing Back draws attention to both its form plainsong is characterised by unaccompanied unison singing in a rhythm that accentuates the lyrics - and to the often-made comparison between football and religion; plainsong is church music. Songs are indispensable to football fans because, aside from their own massed physical presence, bedecked in team colours and the deployment of flags and banners, they have little control over the visual appearance of a stadium that,

\footnotetext{
${ }^{2}$ See also Dabscheck (2007) for a comprehensive account of the political economy of soccer in Australia.

${ }^{3}$ To aid clarity I will use 'Sydney FC fans' when speaking about Sydney supporters in general, and 'the Cove' or 'Cove member' when discussing the views and activities of the club's official fan group.
} 
in the case of Sydney FC, is also home to a rugby league and union team, and an occasional venue for rock concerts. Under such de-territorialized conditions, homeground advantage should perhaps be reconceptualised as home-sound advantage because singing has become the means to territorialize the non-space of the multipurpose stadiums that are increasingly a feature of commodified sport. Significantly, unlike the many forms of 'performative consumption' (Hills, 2002) that may articulate a sports fan's identity, such as wearing a replica team shirt, football songs exist mostly outside commodity relations.

Christopher Small's concept of Musicking is highly useful when analysing football singing. Musicking, suggests Small, is a musical act that 'establishes in the place where it happens a set of relationships, and it is in those relationships that the meaning of the act lies' (Small, 1998: 13). Football songs, understood as an act of musicking, produce identity through their ritualised performance in public spaces. Such secular ritual provides three things: 'an affirmation of community'; 'an act of exploration' [becoming]; 'an act of celebration' (Small, 1998: 95). Therefore, singing a football song marks one's membership of a community, it produces that idealised community and it also celebrates that community, one that includes the team. Football songs are then all about the affective creation of sociability (Maffesoli, 1996). For those who sing them, football songs establish a rhetorical territory (Auge, 1995: 108), 'where one is at ease in the rhetoric of the people with whom one shares a life' (Allon, 2000: 285); albeit in this instance a temporary one.

Secular ritual also has a fourth function: ritual separates those that belong from those that do not (Small, 1995: 96). The ritualised football singing can exclude as well as include, as songs reflect and produce the self/other, insider/outsider binary that defines football culture (Armstrong \& Young, 2008: 179) At its most extreme, football plainsong could be seen as a form of symbolic violence, a way of getting at the opposition, including the opposition team, as Lawrie McKinna, manager of the Central Coast Mariners, explains: 'I think when you're playing in front of a vocal home crowd, it really gives you a lift', but '[I]f you are away from home and you're trying to do a few things and you make a mistake, the crowd gets on your back and puts you off your game (in Hassett, 2008: 67). Ken McLeod's view of sport's music as 'sonically, 
rhythmically, and vocally aggressive' (2006: 536) could certainly be applied in the case of many songs in the Cove's repertoire.

\section{'Master-opposition' or insiders and outsiders}

Participation in ritualised football singing is a marker of a fan's membership of, and commitment to, a particular proto-community (Willis, 1990). As a result, fans may exhibit a high degree of resentment against those who will, for whatever reason, not sing. This dislike is particularly acute if the non-singer is standing at the home-end, which is also named The Cove. This controversial 'sing or fuck off' ideology, as it is referred to by some of the Cove members, is an indication of the serious dislike of those who Richard Giuliannoti calls 'football flâneurs'; (2002: 38) match attendees who consume the spectacle of soccer without making any effort to create it. ${ }^{4}$ The Cove makes its opinion of such flâneurs clear in its fan charter: '[i]f you are in the Cove you are expected to participate in any singing and choreographed displays (banners etc.) we do. Don't join the Cove to experience the atmosphere, join the Cove to create the atmosphere' (This is Sydney Magazine, inside cover 2007) - authentic fans produce their football culture, they do not just consume it. So, although football fans accommodate the commodification of football, through purchasing fan merchandise for example, they also resist this commodification in other areas (see Giulianotti 2005). Moreover, if not singing is a crime, then singing an inappropriate song is only slightly less unwelcome. The 'sing or fuck off' mantra also means 'sing the right song or go somewhere else'.

Like all identity, fan identity has a strong normative streak - authorised songs produce an authorised identity - there is a limited number of ways that you are allowed to imagine the community and, therefore, yourself. This hegemonic struggle over identity is evident in the long threads about songs and singing on the online fan forum: for example one fan complained that:

the last time I was in the cove me and my mate, just the two of us, just for a bit of a laugh (we'd had a couple of beers you see), started singing "the long and winding road" by The Beatles, only for f\#ckstick in a denim vest with northern spirit badges all over it and his retarded mates to turn round and start yelling at us

\footnotetext{
${ }^{4}$ Due to changes in the consumption of football, there is evidence to suggest that younger football supporters are less likely to be involved in communal singing and that, as a whole, singing has been on the decline in the UK (Giulianotti \& Finn, 1999:270).
} 
"SHUT THE F\#CK UP, SHUT THE F\#CK UP! WE DONT SING THAT SONG HERE IN THE COVE!!!" We started singing louder and they threatened violence.

To which another supporter replied:

yeah but think about it this way:

1) 'The Long and Winding Road' doesn't have anything to do with supporting Sydney FC

2) Because you started singing your own song there will be people new to the Cove that will learn that song thinking that its one of our official chants

3) By singing your own songs you're effectively splitting up the Cove into yourselves singing what you want to sing and everyone else singing what the Cove organisers start off. ... WE don't need people to start singing their own chants and making the job even harder than what it already is. [Sydney FC Forum, Sydney-unofficial.com.au: accessed: 12/11/07)

Other forum discussions saw exchanges between those who wanted more songs of simple construction: 'I think some simple chants work best in terms of volume and participation ... simple call and response ones are also really popular' (Sydneyunofficial.com.au: accessed: 12/11/07), and those in favour of greater complexity in the repertoire. Those against adopting easy-to-remember lyrics and melodies argued that an authentic fan would take the time to learn the songs, difficult or otherwise, and that simple songs were an unnecessary and unwanted concession to less committed supporters. Of course, an ability to 'join in' requires cultural capital as well as desire, so in addition to distinguishing them from the fans of other clubs, a fan's ability to sing ranks them within the hierarchy of their own fan group and the Sydney FC supporter community in general.

The centrality of the insider/outsider binary to a fan's identity is also apparent in the songs' lyrics. A simple taxonomy of the Cove's repertoire would comprise only three types of song: those that include, those that exclude and those that do both. The inclusive songs celebrate Sydney, the city, the team, its players and fans, for example:

Sydney till I die

I'm Sydney till I die

I know I am

I'm sure I am

I'm Sydney till I die

(to the tune of 'I am H-A-P-P-Y')

The exclusionary songs, on the other hand, create a parallel series of outsiders: other cities, other teams, other players and other fans. These techniques of othering often rely 
on 'ready-made' local rivalries taken from elsewhere, often without a direct connection to football culture itself. Outsider status may rely on traditional, but non-soccer, antagonism. For example, the metropolitan rivalry between Sydney and Melbourne is drawn upon:
We are one, but we are many
And from all the lands on Earth we come
We share a dream and sing with one voice
I hate, you hate, we hate Victorians
('I am, you are, we are Australian')
[when playing the Melbourne Victory]

Other regional rivalries seem to be of a newer vintage, but again the lyrics draw on widely circulating media stereotypes and social prejudices:

\author{
You're just a slum on the Freeway \\ (Guantanamera) \\ [when playing the Central Coast Mariners] \\ You are a bogan, an ugly bogan \\ You're only happy, on pension day \\ Your Mum's out stealing, your Dad's drug dealing \\ Oh please don't take my hub caps away \\ ('You are my Sunshine') \\ [when playing the Central Coast Mariners] \\ Your sister is your mother \\ Your father is your brother \\ You all fuck one another \\ The Newcastle Family \\ (Adams' family theme) \\ [when playing the Newcastle Jets] \\ (Sydney FC Forum, Sydney-unofficial.com.au: accessed: 12/11/07)
}

In these three examples, the rivalry between the city and the periphery is marked by the alleged poverty, decadence and immorality of the latter.

Significantly, Sydney FC's songs and chants do not appear racist or xenophobic. Article Five of the Cove Charter makes the group's public opposition to racism clear: 'Sydney is a multi-racial society. The Cove reflects this and welcomes everyone' (This is Sydney Magazine, inside cover 2007). Aside from articulating a liberal multiculturalism, the lack of any obvious ethnic references in the songs and chants, where they had once been a common feature (Hughson, 1998: 405), is perhaps an 
indication that those who have worked to 'de-ethnicize' Australian elite soccer have, after many attempts, been successful. ${ }^{5}$

Along with racism, Article Five of the Cove's Fan Charter also prohibits sexism - 'any incidents of racism or sexism will be dealt with' (This is Sydney Magazine, inside cover 2007) - yet this anti-sexist stance is on occasions transgressed. ${ }^{6}$ So, when women are represented in songs, these representations generally conform to the familiar madonna/whore binary (Easthope, 1990: 132). When reading such lyrics as 'Sydney boys, we are here/Shag your women and drink your beer' it is difficult not to agree with Karen Gosling when she argues that sport provides an opportunity for the 'legitimate expression of hypermasculinity' (2007: 253), and notwithstanding the likelihood that such hypermasculinity might begin and end in the singing of such lyrics, it would certainly be interesting to ask the minority of women who participate in the Cove's communal singing how they feel about singing songs which appear to marginalise women in a manner that is common in sports' fan cultures (Gosling 2007). One particular song, directed against Melbourne Victory captain Kevin Muscat, the ALeague's premier folk devil, has the dubious distinction of being misogynistic and homophobic, simultaneously:

Oh Posh Spice is a slapper

She likes it when you thrust it

She likes to take it up the arse

And so does Kevin Muscat

('One Man went to Mow')

Unlike sexism and racism, homophobia is not proscribed explicitly by the fan charter. 'A recurrent terrace theme' (Dunning et al, 1986: 225), homophobic lyrics directed at the oppositions' fans and players are a form of symbolic demasculinization, and a more general feature of ritual anthems developed within masculine subcultural groups (Brottman, 2008: 32). If sports fandom legitimises hypermasculinity, as Gosling suggests, it may also legitimate a hyperheterosexuality and, therefore, the identity boost' (Theodoropoulou, 2007: 325) that results from such symbolic attacks on

\footnotetext{
${ }^{5}$ For a detailed discussion of the relationship between ethnicity and football in Australia see Mosely (1997) and Skinner et al (2008)

6 SFC does have a lesbian and gay supporters group (SLAGS). See http://www.starobserver.com.au/sport/2008/08/13/get-your-ra-ra-on/1200
} 
outsiders, be they fans, players, or officials, may be read as a boost to the insiders' masculinity and heterosexuality.

Songs and ritualised singing are fundamental to the process of local identity formation amongst Sydney FC's fans, and these rituals and songs are as much about exclusion as inclusion. Consequently, fan identity mobilised through song partakes of what Zygmunt Bauman calls the 'master-opposition between the inside and the outside' (1990: 143).

\section{Global songs, glocal fans}

But, if football songs are all about manufacturing a local tribal homeland, why do fans of Sydney FC sing songs about Posh Spice? There is, I would argue, something fundamentally paradoxical about the process of identity formation through football songs. Different groups of fans, who thrive on incommensurability, create their identities by drawing on the same, limited and perhaps even generic song hoard: as a result difference begins to sound a great deal like sameness. This sameness is evident in the song lyrics, which often contain only small local variations, sometimes as small as a single word, and in the melodies which are almost all soccer standards and massmediated pop songs (see Fig 1). ${ }^{7}$

\author{
I am H.A.P.P.Y. \\ The Entertainer \\ When the Saints Go Marching in \\ Crocodile Rock \\ Lord of the Dance \\ We are Sailing \\ You are my Sunshine \\ I am, you are, we are Australian \\ Go West
}

\author{
This Old Man \\ Oops, upside your head \\ Hey Jude \\ Twist and Shout \\ Guantanamera \\ Yellow Submarine \\ My Old Man's a Dustman \\ Fernando \\ Winter Wonderland
}

Figure 1. Sample of the Cove's melody repertoire 2006/7

For example, when playing the Central Coast Mariners Sydney FC fans sing 'You're shit and you stink of fish' to the tune of 'Go West'. Originally recorded by The Village People (1978) and later covered by The Pet Shop Boys (1993), 'Go West' 'has become a staple for many English soccer chants, including "One nil, to the Arsenal," and "Go, West Bromwich Albion” as well as many more vulgar variations' (Mcleod, 2005: 541).

\footnotetext{
${ }^{7}$ Occasionally, a SFC song or chant is even appropriated from another sport: 'The Chop' is taken from
} American baseball. 
'Go West' is also used by fans of teams from non-English speaking countries: FC Schalke's supporters sing 'Steht auf, wenn Ihr Schalker seid' ('Stand up, if you're on Schalke's side'). The long geographical reach of this standardised repertoire was made clear when, during a 2007 Asian Champions League fixture at the Sydney Football Stadium, the Cove and Urawa Reds fans were singing different lyrics, sometimes at the same time, to the same melodies.

The derivative nature of their songs and chants repertoire does not go unnoticed by the fans themselves. After attending matches in Italy, one supporter wrote on the fan forum that when comparing repertoire, the 'similarities [between] the stuff they [Italian fans] sing and the stuff the Cove sings, far out weigh the differences', while a second came to the conclusion that 'I guess it is ok for Sydney FC to pillage recent songs from around the world ...'. Not all agree with such borrowings: 'I have a big problem with a club using another club's song... you do realise that every single song we have is from another club'; 'maybe we could try and be a little different, and not just another poor clone of a British home end'; 'the issue [with] many of those typical Brit songs is that they are universal. Many have little connection to us ...' (Sydney FC Forum, Sydneyunofficial.com.au: accessed: 21/05/08). To those who might subscribe to the overly romantic view that football songs are, or were, a form of authentic local, folk or vernacular music, the proliferation of soccer standards is often negative; this sonic sameness is a ready example of the 'diminishing contrasts' (Maguire 1994) to be found within sport produced by globalisation.

This lack of originality is, however, not a recent phenomenon. Thirty years ago Peter Marsh et al wrote that 'the vast majority of chants are common to virtually all [British] football grounds, with slight variations' (Marsh et al, 2005[1978]: 240). A decade later, in a study of football violence, Dunning et al also noted that '[e]ach fan group has its own repertoire of songs and chants but many of these are local variations on a stock of common themes' (Dunning et al, 1986: 225). Moreover, mass-mediated popular songs have always been an element of football plainsong and indeed such massed singing is itself an invented tradition that, in the UK at least, dates back only to the 1960s. While chanting and singing were part of the football soundscape before this period (Armstrong \& Young, 1999: 180) and the origins of football singing may be traced back to a much older oral culture (Giulianotti \& Finn, 1999: 271), it was only during the 1960s that 
plainsong became a defining element of terrace life as the voices of fans became 'disciplined in song' (Back, 2001: 319). Liverpool fans began singing songs set to Beatles melodies at this time. "The younger sections of the Liverpool Kop "naturally" sang Beatles songs: 'She Loves You' and 'We all live in a Red and White Kop', (to the tune of 'We all live in a Yellow Submarine')" (Long \& Williams, 2005:np). Indeed, Beatles' melodies remain a staple of contemporary soccer fans' repertoire.

Songs have always travelled with the fans that have sung them. Songs travel today, but they go much further, disseminated via global communications networks, through a technologically augmented folk process (Smith 2002). Lyrics, for example, are now circulated via internet forums which operate as virtual word-of-mouth. And with the benefit of second generation web technology, Cove members can now post videos of themselves singing particular songs so that melodies and choreography, as well as words, may be transmitted and learned. Rather than see this musical standardisation at Sydney FC and other clubs as a relatively recent attenuation of a once heterogeneous and authentic local football culture, I would speculate that the singing of soccer standards allows the fans to articulate, simultaneously, a different form of identity, and therefore create a more complex sense of place.

Consumption of football is an experience of glocalisation, an encounter with the 'transnational circulation of labour, information, capital, and commodities that can underpin non-national forms of cultural particularity' (Giulianotti \& Robertson, 2004: 549). Even the most parochial of football fans will find that his or her local team is owned by international shareholders, sponsored by an overseas company, and that their local team contains at least some foreign players brought to the club via a global transfer market. Moreover, in order to watch their club play on television, perhaps in one of the pan-continental cup competitions like the Asian Champions League (itself governed by a continent-wide and globally affiliated administration), these fans will need to subscribe to a transnational media organisation's pay-television service and should they purchase team merchandise, then a similar situation applies. In the context of glocalisation, football plainsong marks both a local identity, what Giulianotti and Robertson would refer to as a 'particularist symbolism' (2004: 550), and, simultaneously, an affiliation to and identification with the imagined global football fan community. Such a 'relativist symbolism' is evinced by 'a cosmopolitan, world 
community of followers who "relativize" themselves into specific cross-national preferences for world players, managers, and clubs' (Giulianotti \& Robertson, 2004: 550) and, perhaps, even songs and chants. This pan-global soccer fan identity is demonstrated by the email signatures of Sydney fans that use the fan forum. Here obligatory mentions of Sydney FC ('Sydney til I die') are augmented by the names of other international club sides, Barcelona, Sporting Lisbon, AC Milan, Roma, Manchester United, and soccer sides from other leagues within Australia. ${ }^{8}$ As well as an indication of football's 'global ecumene', such associations challenge the classic mode of football fandom (Crawford: 2004), which remains singularly partial to a particular team.

\section{Conclusion}

The newly invented tradition at Sydney FC relies on the song repertoires and rituals of a global football culture to create a local identity, one identified as metropolitan, affluent and, unsurprisingly, masculine and heterosexual. More fundamentally, one's identity as an insider is predicated on singing legitimate songs at the appropriate time. From one perspective the apparent standard repertoire of football plainsong at the club's games may indicate the homogenising tendencies of an increasingly globalised and commodified sports culture. References to Posh Spice in a deliberately offensive song directed at Melbourne's Captain Kevin Muscat, and sung to the tune of 'One man went to mow', may seem a trifle second-hand. But when singing such a song, Sydney FC fans are subscribing symbolically to a global football fan identity; local and distant spaces are joined through song. The importance of being part of a global soccer network may be something particularly significant for football supporters in Australia, where despite recent success in the 2006 World Cup, soccer remains on the edge of a febrile national sporting consciousness. Television Broadcaster SBS's branding of soccer as 'The World Game' draws on this global soccer sentiment while excising 'the nation' from the sport's imaginary. Tellingly, of all the songs the Sydney FC supporters sing, only one has a melody that indexes Australia, and Australia as 'the nation' is absent entirely from the lyrics.

\footnotetext{
${ }^{8}$ These signatures might also be a clue to the ethnic identification of Sydney FC supporters. However, under the logic of global fandom, they may also indicate nothing of the sort.
} 


\section{Bibliography}

Allon, F. (2000) 'Nostalgia Unbound: illegibility and the synthetic excess of place', Continuum, 14(3): 275-287.

Anonymous (2007) This is Sydney Magazine, The Cove: Sydney.

Armstrong, G. \& Young, M. (2008) 'Fanatical Football Chants: Creating and Controlling the Carnival', Sport in Society, 2(3):173-211.

Augé, M. (1995) Non-places : introduction to an anthropology of supermodernity, translated by John Howe, London, New York: Verso.

Baumann, Z. (1990) 'Modernity and Ambivalence', in Mike Featherstone (ed.) Global Culture: Nationalism, Globalization \& Modernity, London: Sage.

Back, L. (2001) 'Sounds in the Crowd', in Bull, M. \& L. Back (eds) The Auditory Studies Reader, Oxford: Berg.

Brottman, M. (2005) High Theory/Low Culture, New York: Palgrave.

Crawford, G. (2004) Consuming Sport: Fans, Sport \& Culture, London: Macmillan.

Dabscheck, B. (2007) 'Moving Beyond Ethnicity: Soccer's Evolutionary Progress', in Stewart, B. (ed) The Game's not the Same: the Political Economy of Football in Australia, Melbourne: Melbourne University Press.

Dunning, E., Murphy, P. \& Williams, J. (1986) 'Spectator Violence at Football Matches: Towards a Sociological Explanation', The British Journal of Sociology, 37(2):221-224.

Easthope, A. (1990) What a Man's Gotta Do, Boston: Unwin Hyman.

Giulianotti, R. (2002) 'Supporters, Followers, Fans \& Flâneurs', Journal of Sport and Social Issues, Feb:25-46.

Giulianotti, R. (2005) 'Sport Spectators and the Social Consequences of Commodification: Critical Perspectives from Scottish Football', Journal of Sport \& Social Issues, 29(4):386-410.

Giulianotti, R. \& Finn, G. (1999) 'Old Visions, Old Issues: New Horizons, New Openings? Change, Continuity and Other Contradictions in World Football', Sport in Society, 2(3):256-282.

Giulianotti, R. \& Robertson, R. (2004) 'The Globalisation of Football: a Study in the Glocalisation of the Serious Life', The British Journal of Sociology, 55(5):545565.

Gosling, V. (2007) 'Girls Allowed? The Marginalisation of Female Sports Fans', in Gray, J. et al (eds) Fandom: Identities and Communities in a Mediated World, New York: New York University Press.

Hassett, S. (2008) 'With Undesirables Now off the Menu, Marinators Left to Stew', Sydney Morning Herald Weekend Edition September 20-21.

Hills, M. (2002) Fan Cultures, London: Routledge.

Hobsbaum, E. \& Ranger, T. (eds) The Invention of Tradition, London: Cambridge University Press. 
Long, C. \& Williams, J. (2005) 'Football and Music Cultures in Liverpool', Esporte e Sociedade, 11.

McLeod, K. (2006) 'We are the Champions': Masculinites, Sports \& Popular Culture', Popular Music \& Society, 29(5):531-547.

Maffesoli, M. (1996) The Time of the Tribes, Thousand Oaks: Sage.

Maguire, J. (1994) 'Sport, Identity Politics, \& Globalisation: Diminishing Contrasts \& Increasing Variety', Sociology of Sports Journal, 11:398-427.

Mosely, P. (1997) 'Soccer', in P. Mosely et al (eds) Sporting Immigrants, Sydney: Walla Walla Press.

Marsh, P., Rosser, E., \& Harre, R.(2005) 'Life on the Terraces' [1978], in Ken Gelder (ed.) The Subcultures Reader, $2^{\text {nd }}$ ed., Routledge: London.

Skinner, J., Zakus, D.H. \& Edwards, A. (2008) 'Coming in from the Margins: Ethnicity, Community Support and the Rebranding of Soccer in Australia', Soccer \& Society, 9(3):394-404.

Small, C. (1998) Musicking: the Meaning of Performing \& Listening, Middleton, CT: Weslyean University Press.

Smith, G (2000) Singing Australia: A History of Folk and Country Music, North Melbourne: Pluto Press.

Sydney FC Online Fan Forum (2007) <http://sfcu.com.au/>

Theodoropoulou, V. (2007) 'The Anti-Fan within the Fan', in John Gray et al (eds) Fandom: Identities and Communities in a Mediated World, New York: New York Univ. Press.

Willis, P. (1990) Common Culture, Milton Keynes: Open University Press. 